\title{
Discourse of Difference: Rosa Campbell Praed's My Australian Girlhood
}

\begin{abstract}
The Australian nationalist metanarrative performed "cultural apartheid" over female literary production. Excluded from official discourse and dominant literary genres, women resorted to those available in an attempt to formulate their subjectivity. Hence, their narratives became a means of talking back. Consequently, Rosa Campbell Praed's My Australian Girlhood (1902) demonstrates characteristics of autobiography, travel literature and adventure narrative, and at the same time transgresses the said genres in both their intent as well as their structural characteristics. Additionally, travelling within the colonial context, Praed inevitably participates in the discourses of imperialism, which she is, however, found rupturing as she criticises British racial policy in Australia, thus revealing her writing as double-voiced. As a female colonial writer writing within a masculine realist literary tradition, Praed was othered by contemporary critics who either devalued her writing, or altogether dismissed it as un-Australian, ignoring numerous instances wherein she contributes to the formulation of an $1890 \mathrm{~s}$ identity. Therefore, to read Praed's text means to be aware of this historically and culturally specific context.
\end{abstract}

Key words

Rosa Campbell Praed; My Australian Girlhood; life writing; women writers; double-voiced position; othering

\section{Manipulating the Space that Constrains Her: The Double-Voiced Discourse of Australian Women Writers}

As Gilbert and Gubar have formulated it, "women have historically hesitated to attempt the pen. [...] [and] the woman writer's self-contemplation may be said to 
have begun with a searching glance into the mirror of the male-inscribed literary text" (1984: 15). Traditionally white, male and western, autobiography was such an example par excellence. Consigned by patriarchy to the margins of discourse, women had to work within, as well as attempt to rework, the conventions of available literary forms in order to record their experience. Moreover, they had to battle against adverse conditions in the production, critical appraisal, and distribution of their texts. Therefore, "to read women's autobiographical texts is to attend to the historically and culturally specific discourses of identity through which women become speaking subjects" (Smith and Watson 1998: 22).

The marginalisation of women's literature in publication and critical attention, as well as its exclusion from the Australian literary proto-canon formulated in the 1890s, ${ }^{1}$ was interpreted as "cultural apartheid" (Summers 1981: 35) being performed over female content. Summers argues that "Female art forms have simply been adjudged to occupy a distinct universe, one which is apart from and inferior to male, which is unselfconsciously upheld as the universal model" (1981: 35). Hence, "In context of settling the continent," when "life narrative took on an added importance as people had to invent both their landscape and themselves," and the "community's history and the individual's spiritual life narrative" became "interdependent, inextricable" (Smith and Watson 2001: 97), autobiographies written by women were relegated to the covert culture, positioned in alterity to the overtly nationalistic and predominantly male, Australian tradition. Therefore, for decades they played a minor role in the "quest to relate personal to national meaning" (Hooton 1990: 82).

Male autobiographers, preoccupied mainly with showing "how the life has been the fulfilment of ideas," and written "out of desire to see both shape and an end to one's life, to see the end of everything that has been in flux and process, and at the same time to understand it all" (Hooton 1990: 83), confidently delineated the form of the nation. Female autobiography, too, related the sense of place and the sense of individual identity which corresponded to the "yearnings underlying Australia's bush legend gesture towards human values" (Hooton 1990: 286). This is evident in their love of the land and their emphasis on relatedness. However, as Hooton perceptively notices, it is only a gesture, "for the drives are also profoundly and exclusively male" (1990: 286).

Yet even as they are drawn to the bush and outwardly endorse the Australian legend, the discontinuous, episodic narrative of women's autobiography - one lacking teleological design - constructed an alternative symbolic structure which intimated the presence of a covert women's culture, thus reflecting their doublevoiced position within Australian literature.

This dual subjectivity can be clearly delineated in terms of poststructuralist semiosis by referring to Mieke Bal and van Boheemen's definition of the term as "The discourses it produces [...] (located in) common places, be it institutions, groups or, sometimes, and by accident, individuals. Those common places are the places where meanings meet" (1984: 343). Moreover, Bal and van Boheemen continue: "Precisely because human subjects are split, unstable and dependent, 
meanings are conveyed by and to them and partially fixed in them at the moment they participate in semiosis, thus contributing to their permanent (de)formation" (344). Therefore, the subjectivity of women writers is revealed as a momentary fix in a nodal point where the said discourses meet. It is conveyed by them, as is described above, but it is also, to apply Bal's terminology, conveyed to them by literary critics.

Reflecting the changing attitude to the Australian nationalist myth throughout the twentieth century, Rosa Praed's subjectivity, as formulated in literary criticism, is a prime example of institutional discourse permanently (de)forming an individual's subjectivity.

Namely Byrne, writing in 1895, not only includes Praed among the seven Australian writers of consequence whose works he analyses in his Australian Writers, but also credits Praed with the first "attempt to give an extended and impartial view of the social and political life of the upper classes in Australia" (81), confirming that the author's intention, expressed in the preface to her first novel, Policy and Passion, has been "maintained in most cases throughout her later work" (Byrne 2009: 81). It was to depict

certain phrases of Australian life, in which the main interests and dominant passions of the personages concerned are identical with those which might readily present themselves upon the European stage, but which directly and indirectly are influenced by striking natural surroundings and conditions of being inseparable from the youth of a vigorous and impulsive nation. (81)

Some of the "facts in the intellectual life" of Australians that Praed singled out, according to Byrne, were those that, half a century later, Arthur Angell Phillips formulated as Australian within the "Australian Man of the Bush" tradition (Summers 1981: 36): "their proud self-reliance" and "their frank, natural manners in social customs of native origin," even "their susceptibility to foreign criticism" (Byrne 2009: 82), which Phillips was to term "the cultural cringe" (1980: 112).

Still, subsequent literary criticism established Praed as a colonial writer "more occupied in showing off Australia to an outside audience," thus apparently revealing "a self-consciousness about externals that is against any deep revelations of life and character," only "daubing their pictures with 'local colour' to please eyes likely to be attracted by an unfamiliar surface" (Palmer 1924: 6). Mid-twentieth-century nationalist criticism continued along the same lines, with H. M. Green arguing that, while Praed did concentrate "upon the elements in Australian life and types of scenery that she regarded as most characteristic, and made the most of them," she "drew them all as it were against an English background, as though in contrast with English life and types and scenery" (1961: I, 237). Additionally, "she was less anxious than [the author Rolf] Boldrewood to show her native country in its most attractive colours" (237). Indeed, ends Green, "her feeling for it was different from his" (237). Geoffrey Serle only briefly refers to Praed as one of the three "lady novelists," claiming that she was "infuriating in 
the contrast between [...] [her] acute intelligence and intellectual depth" and her actual novelistic output, but he concludes that it must have been due to the fact that she was bound "by convention of polite female fiction," while she was, "perhaps, more satirical than we know" (1974: 37). ${ }^{2}$ Of these "lady novelists," Serle continues: "How backward-looking they were, how little they reflected contemporary life, and how little of Australian spirit or idealism they showed, how the Bulletin school was almost totally unanticipated" (37-38).

Raymond Beilby and Cecil Hadgraft (1979), although still complaining that Praed does not convey the Australian background in her novels "very vividly," without "the sudden phrase that captures the essential qualities" (29), identified the main themes Praed was concerned with in her writing: the bush, Australian English, the issue of England versus Australia, birth versus breeding, the "social snobbery of real life," and the tragedy that lurks in "the genuine hopes of the pioneers for a better life of their children" (38). While these could seemingly place her among the contributors to the Australian tradition, it is her specific treatment of these themes, her female point of view, as well as her fiction that is "urban Australia in setting," which left the impression of her "setting out to exploit, something like a tourist brochure, the scenes and sights that might interest somebody outside this country" (42), aspects that served to exclude Praed from the Australian proto-canon. However, Elizabeth Webby claims that the accusation of writing for a foreign audience can easily be refuted, since the works of early writers, specifically Rolf Boldrewood and Ada Cambridge, were "originally run as serials in Australian newspapers" while, ironically, the fiction of a number of nationalist writers, such as Vance Palmer, Katharine Susannah Prichard and Eleanor Dark had London imprints (2000: 71). Still, Beilby and Hadgraft, like Serle, conclude that lady novelists "came through, in some odd way, as being unusual people, as more interesting than what they wrote" (1979: 42).

Thus, with the notable exception of Colin Roderick, who in his 1948 biography of Rosa Praed claimed that she "analysed, rearranged, combined, and vivified" the material in her Australian novels with "unbounded intellectual energy," and that her psychological and occult novels reveal "irritability that is the mark of genius" (206), it was not until the work of Dale Spender in the late twentieth century that Rosa Praed received critical acclaim that equals her talent and literary merit, and that the true reason for her exclusion from the proto-canon was finally formulated:

Here is a woman who wrote about the outback, and about political intrigue, about squatters, bushrangers, criminals, governors, knaves and knights: a woman who wrote about oppression, who wrote about the victimisation of women and of blacks. And despite this abundance of "bush realism," here is a woman writer who cannot be comfortably placed within the Australian male tradition, for her view is that of women, and it is very different. And it is this "woman's view" which has been eclipsed. (1988b: 164) 


\section{My Australian Girlhood as an Autobiography of Childhood}

Rosa Caroline Praed (1851-1935) was born at Bromelton, on the Logan River in Queensland. There and at her father's stations in the Burnett district, she spent her childhood. Her father's subsequent political career took her to Brisbane, and exposed her to Queensland politics, in which she took great interest. In 1872 she married Campbell Praed, the younger son of an English banking and brewing family, who had come to Australia to make a pastoral fortune. He had a cattle run, Monte Christo, on Curtis Island near Gladstone, where Rosa spent two miserable years. She describes those experiences in My Australian Girlhood: Sketches and Impressions of Bush Life (1902). The narrative also shows the effects of her 1894-1895 visit to Australia, which stimulated her to remember her childhood. The "then and now" passages identify one of the motifs for her writing, that of nostalgia, of paradise lost, of the myth of the fall (Hooton 1990: 104). In her writing, as, indeed, is the case with much women's autobiography in Australia, as Hooton claims, giving the example of Miles Franklin's Childhood at Brindabella (1990: 105), it is not just the normal adult "fall into self-consciousness" (105) that is at stake, it is also the lament for the deliberate destruction of the paradisal landscape of her youth:

The scrub is gone - the lonely, beautiful scrub which can never be made again. One cannot now hear the dingoes howling and the melancholy note of the morepork, nor the faint crying of the native bear. Instead of the long gum-stretches, there are patches of maize and millet, and where the gumtrees have been cut down on the ridge one has a more distinct view of the mountains. They at least are not defaced. No one can free-select in those fastness. (Praed 1902: 132)

The destruction suffered by the landscape resulting from changes produced by past years is especially hard on Praed, since she endows her childhood home with an "exotic, outworldly aura which challenges the imagination" (Hooton 1990: 359). She perceives the land as speaking to her inner self; and, in terms of motivation and to apply Coe's terminology, Praed's autobiography is a "quest for patterns and meanings in existence" (1984: 75). For her, "Australian landscape poses philosophical questions about human existence" (Hooton 1990: 359). Praed, thus, describes the land of her youth as a determining factor in the development of her character, claiming that her "wild youth 'down under"" (1902: 1) brought to bear on her life one important influence: "My Australian girlhood taught me to love Nature, and to find in the old nurse ever my best friend" (1).

In her quest for meaning, the incidents described are "chosen according to their emotional or metaphysical significance" (Coe 1984: 3). ${ }^{3}$ Thus, when Praed describes her childhood home Naraigin, the rafters in the parlour are remembered "as the home of tarantulas, centipedes and sundry uncanny reptiles" which would "in their perambulations make eerie scratchings," causing the child Rosa to lie awake "in cold terror listening to the sound of the hundred feet of their travels, 
and getting as near to the outer side of the bed as was possible" (1902: 59). To illustrate this atmosphere in which the narrative evolves, Praed introduces photographs. Thus, her discussion of the "convulsions that have torn" (11) Australia into existence is accompanied by a photograph of the rocks near Fitzroy Falls, while the passage about skirmishes between Aborigines and white settlers on the frontier is reinforced by a photograph titled "Attacked by Blacks," showing a white selector defending his home with a rifle (14).

Again, typical of childhood autobiography, ${ }^{4}$ the author's first memory is a pivotal moment. As is usually the case, Praed's too is a clear picture, but like a still photograph, entirely without context. It is of her grandmother and "her boxes." In general, the grandmother is one of the archetypal personages revisited in childhood autobiography (Coe 1984: 120), and Praed's own grandmother is

rather an awesome person, with a long upper lip, grave, piercing, dark eyes, and four shiny black curls, two on each side of her face, which is framed by the border of a huge straw bonnet with a quilling of brown ribbon in the inside. [...] When she smiles, her face ceases to be severe, and the tones of her voice, which were low and pleasant, linger like the sound of a lullaby.

(Praed 1902: 2)

In addition to the grandmother, two additional archetypal figures are described, the father and the mother. They are revealed to the reader through their loveletters, which describe the Australia of a generation ago, and are hence, like the memory of the grandmother, an instance of the "living past surviving into the present," thus "providing stability [...] in contrast to everydayness" (Coe 1984: 120). Similarly, the young fiancée reports on her "Mama" teaching her housekeeping, which is why she believes their marriage should not be hurried, "for what will it matter after we have been together many years, whether our wedding was a month or two sooner or later" (Praed 1902: 38). She also adds an emotional declaration that she does not care, as he does, that he is not rich, for if they ever do become "even rich (the italics are hers) what happiness it will be, knowing that they have shared the bitters as well as the sweets" (38). Young Campbell Praed, in return, reports on the difficulties in keeping a bush farm and building a new house for his future bride.

From these letters, the father emerges as a bushman in keeping with Australian tradition. He emerges the same through the curiosa historica (Coe 1984: 230232) whereby child Rosa gives the "basic material of history "below-stairs" (Coe 1984: 230). In the events following the Frazer massacre, as well as those regarding the establishment of the colony of Queensland, her father is a strong man with a plan and energy to put it to work.

However, as the narrative progresses, the image of the father described above collapses, and he is revealed as a failure, as weak. Additionally, from an enamoured, hopeful young lady, the mother gradually becomes a "second-class citizen," a person "gentle to the point of futility, unassertive to the point of character- 
lessness" (Coe 1984: 95). This "socially powerless" (Hooton 1990: 167) creature reflects the social disadvantages women of her generation faced. It is with this realisation that My Australian Girlhood departs not only from the pattern of a typical childhood autobiography, but also from those narratives supportive of the Australian nationalist myth of the 1890s.

\section{My Australian Girlhood as a Transgressive Autobiography}

Being a text by a female, with its author thus not having to live up to the imperative of "the doing of pioneering" (Hooton 1990: 31), this "memoir of place" (31) allows the female author "substantial freedom to inscribe [her] past selves; not so unequivocally patriarchal as the pioneering record" (31). Additionally, as a woman, an outsider in the eyes of the popular culture, Praed is a "powerful transmitter of a covert culture, which is inherently if unconsciously sceptical of the overt ethos" (286).

The form of her narrative already reveals Praed manipulating the space that confines her as a female writer to romance novels or confessional forms; she stretches the traditionally male genre of autobiography to accommodate the female experience. She weaves autobiography, travel and adventure literature into a single thread of narrative. Ultimately, her struggle with form takes her a step further, such that Praed will deny these genres their traditional intent.

Namely, the traditionally male genre of autobiography, a "success story and history of [his] era" (Jelinek qtd. in Smith and Watson 1998: 9), is employed by Praed as a means of making visible a female subject that was formerly invisible. Next, instead of having been "confined to the home and the private sphere, chaperoned when outside, swaddled in clothes which restricted [her] movements and [having] little or not economic or political choice about [her] life" (Mills 2001: 27), Praed not only ventured outside, but also decided to write a record of her early life and travels in the Australian bush. Finally, even as she employs the genre of adventure narrative common to the period, she transgresses its original intent, which is to celebrate the empire, for "imperialist discourse [is] [...] a manmade discourse, expressing male fantasies, fears, anxieties" (Stott qtd. in Mills 2001: 77). On the other hand, Praed's narrative, in a number of instances, questions, even openly criticises, the imperialist project.

Taking into account current emphasis on historically specific regimes of truth and knowledge in the production of subjectivity described above, ${ }^{5}$ Rosa Praed's authorial self is revealed to us as a singular anomaly within the accepted context of women's writing in the middle of the nineteenth century - even more so, as her writing is revealed as double-voiced, both conforming to and transgressing the "regularities of discourse" (Mills 2001: 73), and striving to describe the female experience of life in nineteenth-century Australia. The process is most manifestly revealed in the instances of the narrator, the narrative structure, and the types of events (Mills 2001: 73-94) incorporated into the narrative. 
In her study Imperial Eyes: Travel Writing and Transculturation, Mary Louise Pratt differentiates between two types of narrator: the Linnaean emissary, one who observes and documents geography, flora and fauna, a "naturalist as Adam in his garden" (1992: 51), and the sentimental hero who writes of himself as of a protagonist of "an epic series of trials, challenges, and encounters with the unpredictable" (75). The first type tends to efface himself and "what is narrated is a sequence of sights or settings. Visual details are interspersed with technical and classificatory information" (59), and is usually associated with the panoramic gaze. The information given is "relevant (has value) in so far as it attaches to goals and systems of knowledge institutionalized outside the text" (77). Contrary to the scientific narrator, the sentimental one "explicitly anchors what is being expressed in the sensory experience, judgement, agency or desires of the human subjects. Authority lies in the authenticity of somebody's felt experience" (76). Since women were, within Victorian mythology, associated with the private sphere, it is hardly surprising that their travel writings tended to employ a sentimental narrator. Or as Pratt clearly states:

If, as I suggested earlier, the landscanning, self-effacing producer of information is associated with the panoptic apparatuses of the bureaucratic state, then this sentimental, experiential subject inhabits that self-defined "other" sector of the bourgeois world, the private sphere - home of desire, sex, spirituality, and the Individual. (78)

Since My Australian Girlhood is a narrative of Praed's young self to whom she fondly turns - which may well be, as Roderick writes, "a common experience of old age" (1948: 201) - Praed's narrator is inevitably not the distanced narrator focused on professional life, telling a history of her era (See Jelinek qtd. in Smith and Watson 1998: 9). Rather, her narrator emphasises personal and domestic details, describing connections to other people (See Jelinek qtd. in Smith and Watson 1998: 9), thus displaying characteristics of Pratt's "sentimental narrator."

My Australian Girlhood begins with Praed's first recollections - those of a journey through the bush towards her father's Naraigin Station. The narrated "I" (Smith and Watson 2001: 60-61) is "a small child dressed in a Holland overalls with rows of wavy red braid upon it and a sunbonnet dangling from [her] bare neck, perched with Tommy upon those very sliprails that dipped into the bog" (Praed 1902: 57). As it meant life in the neighbourhood of the Blacks' camps, "all men we used to know in those days carried revolvers that bit little children" (58). Since Victorian women - and, thus, a female child as well - would be confined to closed spaces (except for a few instances that would have been tolerated, in a child), the skirmishes between white settlers and the Aborigines in this frontier country are described as stories a child overheard the squatters telling on the verandah of the Naraigin slab house, ${ }^{6}$ causing the female child to see "in imagination vivid pictures of fierce and bloody fights" (98). The move to Brisbane, even though this was the exciting period of the birth of the new colony of Queensland, 
for a bush child meant a tedious life in "highly civilised conditions" with "no iron-bark gums, oozing glorious stickiness [...] no saw-pit theatre: no shipwrecks in the cutter: no splashings on the shingle" - only the "schoolroom routine carried on in a sawn-wood hut extemporaneously erected in the back-yard of a new two-stories Brisbane row, built on London suburban lines, with no shady verandahs, nor lean-tos, nor anything else deliciously Australian" (120). The "prisoners" of the back-yard were soon relocated to Marroon Station, which meant life in a country which "seemed to spread to the horizon like a blue, undulating sea broken by precipitous islets," with "monotonous grey-blue of gum-trees, eternal and ever present" (137). Finally, the misery of Curtis Island is foreshadowed by the "waifs, who in sheer desperation of loneliness, discomfort and nervous terror, had fled incontinently from their inhospitable, sea-girt abode" (255), just as the Campbell Praed's were disembarking. It is the language of emotions which "assigns value to events" (77).

Not only does Praed employ a sentimental narrator traditionally attributed to women writers, but she also formulates her narrating self in line with the dominant discourses of the time that governed Australian colonial ladies. She depicts herself as a female child who had "nights of camping out between earth and open heaven" the camp fire throwing "leaping lights upon the trunks of the gums, so that the naked branches gleam[ed] gaunt" (83), but a child educated by private tutors reading "David Copperfield with the original illustrations" and "a bit of Byron" (56), as well as Hans Christian Andersen's fairy tales. In Brisbane, "a brand-new town governess" taught her "Queens of France," there were "music lessons too scales and exercises - 'one, two, three, and thumb under': and the little savages learned French [...] and dancing" (121). She moved in high social circles; she went on "walks in the Botanical Gardens, where they occasionally saw the Governor taking a stroll [...] and her Royal Highness [...]" (121). Thus, to an adult married woman, the crude conditions on Curtis Island were too much to bear. Namely, Praed's memories of her life there give "a picture of the amateur cook, [...] subsiding in tears upon a three-legged stool in front of the open American oven [...]. The fire was made of logs of wood, often inadequately chopped and of inconvenient angles" (267). Dismayed, and on the verge of exhaustion, she was soon brought "back into civilisation" (270), to her father's house in Brisbane. Later, she was to write that she had "only ugly ghosts to lay [at Curtis Island]" (Clarke 1999: 38-39).

Even though Praed formulates her narrating self within the spatial logic of "sessility" - to employ a botanical term Eric J. Leed applied when describing the women's condition of being always "at home" (Leed qtd. in Smith 2001: x) assigned to women within Victorian mythology -or, as Karen R. Lawrence observes in Penelope Voyages, within the logic of the female body being in effect "home itself, for the female body is traditionally associated with earth, shelter, enclosure" (1994: 1) - she manipulates the available genres in an attempt to describe Australian life "truthfully."

In short, Praed was self-confidently "Australian," and she used her Australian identity for her narrating self to claim "authority of experience" (Smith and 
Watson 2001: 27) over the Australian content. She used it to give England exotic adventure narratives - not simply for commercial reasons, but also because she "knew the advantages of appearing as an authority on adventures in the antipodes and was happy to use her Australian origins to this end" (Spender 1988a: 202). Praed wanted to move away from the English models her Australian literary predecessors adhered to, and sought inspiration in the life around her. Like her fellow female writer Ada Cambridge, Praed aspired to present a "true" image of Australia. She told her father, Thomas Murray-Prior in a letter, dated 14 January 1869 , that she was trying to write simply about "mere everyday experiences" and “"truthfully' ... without any false sentimentalism" (Clarke 1999: 25), of which she accuses her male predecessor Henry Kingsley.

Praed's autobiography is, thus, prime proof of the act of remembering being socially conditioned (cf. Smith and Watson 2001: 18): what and why she remembers are radically different from the story of Australia presented in male narratives. Praed is interrogating the dominant cultural stakes through an alternative mode. Specifically, Praed departs from the conventions of the autobiographic genre, by the adaptation of the narrative structure of an adventure narrative, which is My Australian Girlhood. In contrast to typical examples of imperialist discourse expressing male fantasies and anxieties, Praed's adventure narrative not only departs from its original intent, with the narrator expressing doubts and occasionally openly criticising the British imperialist project, but the bush of her narrative is also not a backdrop of stories of colonial possession, entrepreneurship and adventure. In the most extensive study of these issues, Women and the Bush: Forces of Desire in the Australian Cultural Tradition (1988), Kay Schaffer claims that the dominant impulse behind travel writing is also "one towards ownership, mastery or possession of land, which might consolidate and guarantee identity to the subject" (1988: 80). The subject, Schaffer adds, is constructed as "masculine identity with reference to the otherness of the land," which is revealed already in the act of naming which "takes place within a symbolic order of masculine sameness with reference to masculine and feminine categories" (80). The land is, consequently, represented through the metaphor of the female body. Schaffer further observes that "The assumption that the masculine (man, Empire, Civilisation) has an unquestioned God-given right to subdue or cultivate the feminine (woman, Earth, Nature) and appropriate the feminine to masculine domination is a constant structuring principle of Western discourse" (82).

Hence, My Australian Girlhood attaches no easy blame when it describes the brutalities committed by both blacks and whites in the frontier, which won Praed the attribute of an "unpopular radical" (Spender 1988a: 203). For example, she completely supported Attorney-General Plunkett's declaration that "not only should these men be hanged, but that any white man who could be proved to have killed a blackfellow not in self-defence should be held guilty of murder" (Praed 1902:16). Not only that, she also praised Plunkett for treating blacks as human beings: "All hail to thee, Plunkett! Had there been more like thee, the national conscience would have less cause for self-reproach" (17). In support of her thesis, 
Praed describes her younger self living in harmony with Aboriginal children; and, indeed, a "half-caste boy called Ringo," she claims, was "the first object of [her] youthful affections" (65). Ringo helped her to become acquainted with the landscape they encountered; he showed her "the flesh of the iguana and that especial delicacy, the eggs of the black snake" (66). He taught her to "play dilly-bags, to chop sugar bags (otherwise hives of native bees) out of trees, to make drinking vessels from gourds, and to play the jew's-harp [...]" (66). Even as she was describing the experience of the Aborigines, Praed was aware of the weakness of her voice, hence she writes: "There has been no one to write the Black's epic; not many have said words in their defence; and this is but a poor little plea that I lay down for my old friends" (73).

Praed's description of the women's experience of the bush really reveals their victimisation in this settler society. That experience, however, significantly corresponds to its presentation within the Australian tradition. It commences with a story of her mother, who, even as a girl, had to worry about a drought at their station, their "bush" being burnt down, their waterholes going dry, and their horses and cattle dying in bogs because they lacked the strength to extricate themselves and because all the while her "Papa" was sitting "in the little parlour writing poetry" (39-40). My Australian Girlhood also brings a touching description of her young mother getting ready for childbirth in a bush hut: "'Having neither doctor nor nurse,' the young mother writes, 'and knowing that I might die before there was any hope of medical assistance, I endeavoured to prepare my mind for leaving this world.' Poor little bride of nineteen!" (51). Lastly, the mother was affected by sandy blight:

Those dark-lashed blue eyes of the girl-wife at Bungroopim - Irish eyes which were so large and soft - became contracted and watery, and spoiled by reddened lids, and thinned lashes from the frequent use of lotions. For two years she had to live in a room from which every particle of light had been excluded, by hanging up blue blankets over the windows - the only curtains procurable in the bush. (108-109)

There is also the archetypal story of a woman, lost in the bush, who is separated from her child, a child subsequently found dead by the search party: "[...] the woman lost her reason, and died soon afterwards, in the asylum of the district" (107). Finally, there are Rosa's own memories of the bush, such as the want of good domestic help, a frequent complaint among bushwomen - in reference to Unbroken Filly, "a child of nature who wasn't much of a servant" (205) - as well as references to battles with ants, pests, flies, snakes, centipedes and scorpions while keeping the household in order: "The legs of the dining table had to be put in pint pots filled with water, to prevent the white ants from climbing up and devouring our food" (108). The years Praed spent on Curtis Island were spent in a house that "had not been cleaned for months, the boards in the best bed-room were inch-deep in mire, and a plank across two chairs served as a washstand, 
while the incongruity between lace-frilled cambric and the duties of maid-of-allwork was distressing" (263). This opinionated and resolute narrator casts doubts on the construct, elsewhere presented, of the narrating self of the genteel Victorian lady.

The answer to this should, perhaps, be looked for in Dale Spender's observation that "while there is much that is autobiographical in [Praed's] fictional world, there is very little that is personal" (1988a: 214). As in her fiction, so in her autobiography: Praed's writing, to a great degree, conformed to the expected public picture of her own self, so that, as Spender claims, there is as much "if not more - to be gleaned about the author from reading between the lines as there is from reading the lines themselves" (214).

As a woman consenting to conform to the spatial logic of the private sphere (since the space was so gendered within Victorian mythology) and yet concurrently writing about the outback as the archetypal Australian topos, Praed necessarily produced double-voiced writing. The experience that resulted from spatial mobility beyond "the house" was, however, not direct, but rather mediated. In her writing, Praed deals with the issue of access to knowledge resultant from mobility, by retelling the stories of other people. Thus, Praed narrates the corroboree preceding the Frazer Massacre, the Massacre itself, and the subsequent vengeance parties; the arrival of the Governor to the new state of Queensland; station life; life among the selections; bush hospitality; an escaped convict turning bushranger; and life on the diggings.

The types of events listed above reveal Praed's contribution to Australian literature, as one "well within that emerging Australian tradition" (Spender 1988b: 170), which is also how Praed herself saw her work. In the aforementioned prefatory note to Policy and Passion (1881), she wrote that

It can be no matter of conjecture that when in the course of years Australia [...] will possess a literature of her own as powerful and as original as might be prognosticated, from the influence of nature and civilisation brought to bear on the formation of a distinct national type. (Praed 1881: iv)

Her claim that "it is to the British public that I, an Australian, address myself with the hope that I may in some slight degree aid in bridging over the gulf which divides the old world from the young" (Praed 1881: vi) reveals her identifying with the emerging literature of Australia.

Years later, this true Australian wrote: "I have never felt either English or Irish though nearly all my life has been spent in the British Isles. Always have I had the sensation of being an alien in London crowds whether fashionable or vulgar, $\&$ have in my fancy borne the stamp of the Bush" (Clarke 1999: 41). Nonetheless, she was, however, left out of the Australian literary canon when "Australian chauvinism" (Spender 1988b: 170) made its presence felt to such an extent that anything written by a woman was considered un-Australian. 


\section{Conclusion}

As she began addressing the controversial topics of the day, Rosa Praed raised suspicions, for this compliant Victorian lady was revealed, instead, to be a remarkable colonial intellectual. She was then advised by "many [...] publishers and editors [...] to 'tone down' her writing" (Spender 1988a: 213). George Bentley, the original editor and publisher of Policy and Passion, wrote: "One has to remember that it has your name on the title page, and that you cannot so well say what Mr Praed may" (qtd. in Clarke 1999: 59). Put simply: "At the height of Victorian morality and circumspection" Praed's "frankness and freshness" was sometimes found offensive (Spender 1988a: 213).

Praed did "tone down," as both her biographers suggest (Roderick 1948: 8288; Clarke 1999: 58-60), but "it was certainly not to the point of blandness," argues Spender, for Praed still managed to introduce into her writings some of the contentious subjects "which prompted serious debate and analysis" (1988a: 213). Taking into account Bentley's argument quoted above, Spender may be very close to the truth in claiming that "Perhaps the criticisms that were made about her challenge to convention were more to do with her stand as an independent and articulate woman - rather than with her lack of polish as an Australian" (Spender 1988a: 213).

Namely, Rosa Praed was a talented story-teller who used her writing to address the boiling issues of her age: "She tried to use her writing to enhance understanding, to promote debate, to inform individual and social actions" (Spender 1988b: 173). Educated and open-minded, yet living in the nineteenth century, she necessarily found herself on the margins of the imperialist project. While she is not completely innocent of its enforcement through narration, she still found space in the lines of her narrative to question the "use and abuse" of the project, while her male counterparts "were extolling the virtues of brute force (in 'taming' their environment)" (Spender 1988b: 173). Specifically, "At a time when the literature of men was moving towards a sense of nationalistic confrontation and conquest, Rosa Praed [...] was giving her attention to the victims of such values and adopting a cross-cultural rather than a nationalistic point of view" (Spender 1988b: 173-174). This, however, was executed in a specific type of transgressive autography that contemporary criticism was not able to accommodate thematically or in terms of genre within the male-dominated nationalist tradition; hence, it is not surprising that Rosa Praed was left out. However, reclaiming Praed's oeuvre would mean gaining "valuable alternative insights and understandings" (Spender 1988a: 204) about Australia, insights and understandings which have been absent from mainstream Australian literature and culture for decades. 


\section{Notes}

1 Excluded from the proto-canon in the 1890s, those women writers were overlooked in subsequent decades as well, because, as Betty Birskys writes, it is especially hard for older women writers to enter the arena, women who "had their voices silenced" by passing literary fashions as well as "the hard practicalities of marriage, work, children [...] In writing - as in business, academe and the professions - such women too often find the gates already shut. Publishers and funding bodies seek 'young writers of promise.' The older woman is easily overlooked - and silenced once again" (Birskys 1995: 73).

2 Writing about another "lady novelist," Ada Cambridge (1844-1926), Susan Sheridan gives an ingenious reply to this statement: "But how off the female version sounds, if I say: Perhaps Boldrewood and Clarke were writing mainly for men, for this might explain why they accepted the distorting heroics of male adventure fiction, within which limitation they may, for all I know, be making profound metaphysical comments on life as men experience it; still, they never realised their potential" (1995: 6).

As opposed to the factual significance of events in adult autobiographies (Coe 1984: 3).

See Coe (1984: 98).

Primarily in the theories formulated by Michel Foucault and his influential Power/Knowledge Selected Interviews and Other Writings 1972- 1977 (New York: Pantheon Books, 1980).

6 The exception to this is an Aboriginal corroboree and the Hornet Bank Massacre of 27 October 1857, when the widow Mrs. Martha Frazer, her four daughters, three of her sons, a tutor and two shepherds were massacred by Aborigines at Hornet Bank Station just west of Naraigin, as well as the subsequent hunting of "Blacks" undertaken by the squatters of the area. Those Praed describes as if she had witnessed them. However, not only do her father's notes reveal that she was mistaken about the chronology (She claims that the corroboree preceded the attack, while the father claims it was the other way around), but it is "clear that [her father] would not have taken a six-year-old child on such a dangerous mission" (Clarke 1999: 17). How much the events described came from Praed's own memory or her father's notes is ultimately of less importance than that Praed remained haunted by those events for the rest of her life: "her highly imaginative mind overhung with never-resolved questions of guilt and fear. She believed she had taken part 'in sweeping away of the old race from their own land"' (Clarke 1999: 18-19).

\section{References}

Bal, Mieke, and Christine van Boheemen (1984) 'The Rhetoric of Subjectivity'. Poetics Today 5(2), 337-376.

Beilby, Raymond, and Cecil Hadgraft (1979). Ada Cambridge, Tasma \& Rosa Praed. Melbourne: Oxford University Press.

Birskys, Betty (1995). 'Remember the Pink Elephant?' Hecate 21(1), 70-73.

Byrne, Desmond (1896) Australian Writers. London, R. Bentley \& Son.

Cambridge, Ada (1904) Thirty Years in Australia. London: Methuen.

Clarke, Patricia (1999) Rosa! Rosa! A Life of Rosa Praed, Novelist and Spiritualist. Melbourne: Melbourne University Press.

Coe, Richard N. (1984) When the Grass Was Taller. New Haven and London: Yale University Press.

Gilbert, Sandra M., and Susan Gubar (1984) The Madwoman in the Attic. New Haven and London: Yale University Press.

Green, Henry Mackenzie (1961) A History of Australian Literature: Pure and Applied. 2 vols. Vol. I: 1789-1923. Vol. II: 1923-1950. Sydney: Angus and Robertson. 
Hooton, Joy (1990) Stories of Herself When Young. Melbourne: Oxford University Press.

Lawrence, Karen R. (1994) Penelope Voyages. Ithaca and London: Cornell University Press.

Mills, Sara (2001) Discourses of Difference. An Analysis of Women's Travel Writing and Colonialism. New York: Routledge.

Palmer, Nettie (1924) Modern Australian Literature. Melbourne and Sydney: Lothian Books.

Phillips, Arthur Angell (1980) The Australian Tradition: Studies in a Colonial Culture. $2^{\text {nd }}$ ed. Melbourne: Longman Cheshire.

Praed, Campbell Rosa (1902) My Australian Girlhood: Sketches and Impressions of Bush Life. London: T. Fisher Unwin.

Praed, Rosa (1881) Policy and Passion: A Novel of Australian Life. 3 vols. London: Richard Bentley \& Son.

Pratt, Mary Louise (1992) Imperial Eyes: Travel Writing and Transculturation. London and New York: Routledge.

Roderick, Colin (1948) In Mortal Bondage: The Strange Life of Rosa Praed. Sydney and London: Angus \& Robertson.

Serle, Geoffrey (1974) From Deserts the Prophets Come: The Creative Spirit in Australia, 17881972. Melbourne: William Heinemann.

Sheridan, Susan (1995) 'Ada Cambridge and the Female Literary Tradition'. In: Along the Faultlines: Sex, Race and Nation in Australian Women's Writing, 1880s - 1930s. St. Leonards: Allen \& Unwin.

Smith, Sidonie (2001) Moving Lives. Minneapolis and London: University of Minnesota Press.

Smith, Sidonie, and Julia Watson (2001) Reading Autobiography. Minneapolis and London: University of Minnesota Press.

Smith, Sidonie, and Julia Watson (ed.) (1998) Women, Autobiography, Theory. Madison: University of Wisconsin Press.

Spender, Dale (1988a) 'Rosa Praed: Original Australian Writer'. In: Adelaide, Debra (ed.) A Bright and Fiery Troop: Australian Women Writers of the Nineteenth Century. Ringwood, Victoria: Penguin. 199-215.

Spender, Dale (1988b) Writing a New World: Two Centuries of Australian Women Writers. London and New York: Pandora.

Summers, Anne (1981) Damned Whores and God's Police: The Colonization of Women in Australia. Ringwood, Victoria: Penguin.

Webby, Elizabeth (2000) 'Colonial Writers and Readers'. In: Webby, Elizabeth (ed.) The Cambridge Companion to Australian Literature. Cambridge: Cambridge University Press. 50-73.

Tihana Klepač obtained her Ph.D. in the postgraduate program in literature, culture, performing arts and film at Faculty of Humanities and Social Sciences, University of Zagreb, Croatia. Her dissertation was titled Storykeepers: Australian Myth in the Works of Henry Lawson and Barbara Baynton. She is a teaching assistant at the Department of English, Faculty of Humanities and Social Sciences, University of Zagreb. She has published in Književna smotra, Umjetnost riječi and Studia romanica et anglica Zagrabiensia, and has co-edited Irish Mirror for Croatian Literature: Theoretical Assumptions, Literary Comparisons, Reception with Ljiljana Ina Gjurgjan. Her research interests include white settler literature of Australia, and women's life writing.

Address: Dr. Tihana Klepač, Department of English, Faculty of Humanities and Social Sciences, University of Zagreb, Ivana Lucica 3, 10000 Zagreb, Croatia. [email: tklepac@ffzg.hr] 
